\title{
Self-Concept, AtTitude And Perception OF Usefulness OF Physics And Chemistry ACCORDING TO TYPE AND LOCATION OF SCHOOLS
}

\author{
Inzahuli Samuel Majere, ElizabethRole \\ and Lazarus Ndiku Makewa
}

This study was an attempt to test if students differed in their self-concept, attitude and their perception of the usefulness of Physics and Chemistry in terms of their type of school and location. To test this hypothesis, $t$-test was used to compare differences in the mean scores in terms of type of school and location. Pearson's Product Moment Correlation coefficient was used to determine the relationships between independent and dependent variable. Four hundred and forty six (446) students constituted the sample. The attitude towards Physics and Chemistry and the perception of the type of school showed there was no significant difference between single-sex and coeducational school. There was no significant difference between single- sex and coeducational school (mixed) students in their self-concept in Physics and Chemistry. There was no significant difference between single- sex and co-educational school (mixed) students in their perception of the usefulness of Physics and Chemistry. Results also show that urban students have better perception of the usefulness of Physics and Chemistry than the rural students. The difference in perception of the usefulness of Chemistry is statistically significant but the difference in perception of the usefulness of Physics is not statistically significant. Both rural and urban students had positive attitude and self-concept for Physics and Chemistry.

KeYwords: Self-Concept, Attitude, Perception, Physics, Chemistry

\footnotetext{
Inzahuli Samuel Majere $\mathbb{\square}$

Teacher, Mosoriot Teachers College, Kenya

Email: inzahulisam@yahoo.com

Elizabeth Role

Director of Graduate Studies \& Research, University of Eastern Africa, Baraton, Eldoret, Kenya

Email:bethrole@gmail.com

Lazarus Ndiku Makewa

Dean, School of Education, University of Eastern Africa, Baraton

Email:ndikul@gmail.com
} 


\section{INTRODUCTION}

The purpose of this study was to investigate if students differed in self-concept, attitude and perception of the usefulness of Physics and Chemistry in terms of school type and location. The present study, therefore, followed this line of trend, first by establishing what literature has indicated, secondly looking at the method used, before giving the findings, conclusions and recommendations.

The Kenya National Examination Council Certificate of Primary Education (CPE) Newsletter of July 1983 tabulated results of urban and rural settings for a five-year period from 1978 to 1982 as shown below.

\section{Table 1}

\section{CPE Results Indicating Total Percentage Passes of Rural and Urban Schools} from 1978 to 1982.

\begin{tabular}{|c|c|c|c|c|c|}
\hline $\begin{array}{l}\text { Year of CPE } \\
\text { Type of school }\end{array}$ & $\begin{array}{l}1982 \\
(\%) \\
\text { Pass }\end{array}$ & $\begin{array}{l}1981 \\
(\%) \\
\text { Pass }\end{array}$ & $\begin{array}{l}1980 \\
(\%) \\
\text { Pass }\end{array}$ & $\begin{array}{l}1979 \\
(\%) \\
\text { Pass }\end{array}$ & $\begin{array}{l}1978 \\
(\%) \\
\text { Pass }\end{array}$ \\
\hline Rural & 43.7 & 40.9 & 45.9 & 46.7 & 39.5 \\
\hline Urban & 45.1 & 44.3 & 46.3 & 49.1 & 43.7 \\
\hline
\end{tabular}

(Source: Kenya National Examination Council, CPE Newsletter of July 1983)

As the analysis shows, rural schools consistently trailed behind the urban schools. The study titled 'The sensitivity of school effectiveness' by Madaus et al. (1979) published in the Harvard Educational Review Journal provides evidence that the difference in secondary school characteristics contribute to disparities in student's achievement. The study 'Differences between rural and urban backgrounds' attributed to Felder et al (1995) in the Journal of Engineering Education concluded that students from urban and semi urban backgrounds consistently outperformed their counterparts from rural and small town backgrounds.

The study titled 'An input- output analysis of the achievement levels of secondary schools in Dominica' done by Polydore (2000) established that in developing countries, there were glaring disparities between secondary schools in terms of their student ability at intake, physical facilities and resources, and various constraints imposed by their physical environment and the authority managing them.

This line of research is important as student academic achievement may be related to self-concept, attitude and perception and the use of self-regulated learning (Zimmerman \& Kitsantas, 2005; Zimmerman \& Martinez-Pons, 1990). In addition, there is a need to examine the influence of school location on academic achievement, as rural students tend to have lower educational aspirations (e.g., Arnold, Newman, Gaddy, \& Dean, 2005; Cobb, McIntire, \& Pratt, 1989; Hu, 2003) and place less value on academics (Ley, Nelson, \& Beltyukova, 1996; Stern, 1994) than non-rural students, which may influence the 
way they approach learning.

Over the past 20 years, research has indicated that the educational aspirations of rural youth lag behind those of their urban counterparts (Arnold et al., 2005; Cobb et al., 1989; Eider, 1963; Haas, 1992; Haller \& Virkler, 1993; Hektner, 1994; Hu, 2003; Kampits, 1996; Kannapel \& DeYoung, 1999; Khattri, Riley, \& Kane, 1997; Stern, 1994). For example, using descriptive statistics from the National Education Longitudinal Study of 1988 (NELS: 88), Hu examined educational aspirations and post secondary access by students in urban and rural schools. Using 10th graders as a baseline population, the study found that higher percentage of rural students had aspirations for high school or below (16.6\% for rural, in contrast to $11.0 \%$ for urban students) and for two-year college education (33.1\% for rural, in contrast to $27.1 \%$ for urban students), and lower percentage of rural students had aspirations for four-year college education or beyond (50.2\% for rural, in contrast to $61.9 \%$ for urban students). The study also found that smaller percentages of students in rural schools were enrolled in post secondary institutions (51.1\% for rural, in contrast to $57.4 \%$ for urban students).

Another line of literature suggests that, compared with urban students, rural students tend to have lower educational aspirations, place less value on academics, and have lower academic motivation (e.g., Arnold et al., 2005; Hu, 2003; Kannapel \& DeYoung, 1999). These differences further suggest that rural and urban students may approach their learning differently, as students' perception of the instrumentality of the present academic tasks to obtain future goals influence their use of self-regulation strategies, deep-processing study strategies, effort, and persistence (Miller \& Brickman, 2004; Schutz, 1997).

The empirical issue dealt with in the examples presented below is an important one for education policy. It concerns the effects of school location on math and science achievement trends. A school cannot usually change its location, yet location conceivably may have consequences for how well students learn at the school. The investigation of a rural gap in academic achievement has been recently explored in studies conducted in the USA (Fan \& Chen, 1999; Greenberg \& Teixeira, 1995; Roscigno \& Crowley, 2001; Reeves \& Bylund, 2005), in Australia (Webster \& Fisher, 2000; Young, 1998, 2000), and in cross-national comparisons (Williams, 2005). In the USA, rural education is associated with disadvantage in the public discourse. While research on this matter has not yielded consistent results (Fan \& Chen, 1999; Roscigno \& Crowley, 2001; Israel, Beaulieu, \& Hartless, 2001), it is reasonable to hypothesize that, if rural disadvantage does exist, it is likely to be found in significant learning gaps in mathematics and science. Rural schools are disproportionately likely to have an inadequate pool of teachers qualified in these subjects and insufficient funds to maintain up-to-date computers, instructional software, and laboratory facilities (Education Alliance, 2004; Williams, 2005). 


\section{School Type And AcAdemic Performance}

An analysis of data from the 'Science Survey of the International Association for the Evaluation of Educational Achievement' by Kelly and Smail (1986) established a positive zero-order correlation between science achievement and single-sex schools for girls in England and Australia, but in Italy, performance was better in co-educational schools. Differences have been found in achievement between students in different school types. Studies done in this regard showed that parents preferred single-sex secondary schools for their children. These schools tended to perform better academically compared to coeducational schools.

The book 'The Missing Half' by Harding (1980) in considering the performance of boys and girls in $1974 \mathrm{O}^{\prime}$ Level science examinations found that girls from single-sex schools tended to be more successful than those from coeducational schools.

In the survey on 'Comparative Attainment in English in Single-sex and Coeducational Grammar Schools' by Dale (1964) published in Educational Research, made a detailed analysis of the marks gained in English language and literature in the O'Level examination for the Northern Ireland Senior Certificate in 1959. The findings revealed that students from single-sex schools outperformed their counterparts in co-educational schools in the science subjects.

In an article titled 'Girls Poor Grades in Science Worry Lucy', attributed to Lucy Irungu, the Principal at the University of Nairobi's college of Biological Physical Sciences (2004), published in Biosafety Newspaper, it was argued that girls in single-sex secondary schools tended to do better because there was no one to intimidate them and they were encouraged to believe in themselves. Such girls in single sex schools could venture into anything and develop confidence. The article added that girls in co-educational schools could feel intimidated by their male counterparts, be distracted or easily fall victim to widely held stereotypes like sciences for men and arts for women.

\section{STUdENTS' SELF-CONCEPT AND ACADEMIC ACHIEVEMENT}

Students' self- perceptions vary from situation to situation and from one phase of their lives to another (Woolfolk, 1998). These perceptions are influenced by a number of factors such as evaluations of significant others, reinforcements, and attributions of behavior (Shavelson et al., 1976). It further refers to the set of perceptions or reference points what the subject has about him: the set of characteristics, attributes, qualities and deficiencies, capacities and limits, values and relationships that subject knows to be descriptive about its own and which he perceives as data concerning his identity (Sanchez and Roda, 2007).

The multifaceted and hierarchical model of self-concept suggested that general self-concept has four domains: the academic self-concept, social self- 
concept, emotional self-concept and physical self-concept (Shavelson et al., 1976). The academic self-concept can be divided further into second order specific subject self-concepts like English, History, Mathematics, and Science etc. which can explain learner achievement in each subject.

According to Ormrod (2000), there are three factors, which definitely do influence the degree to students from positive or negative self-concept: Their own prior behaviors and performance, the behaviors of other individuals toward them, the expectations that others hold for their future performance. Each one offers insights as to how teachers can enhance their students' selfconcept. Researchers have been concerned with analyzing of relationships, both associative and predictive between self-concept and academic performance. Purkey (1970) for example, observed that there is a persistent and significant relationship between the self-concept and academic achievement and that change in one seems to be associated with change in the other. Ahmed (1986), Gordon (1997), Haque and Sarwat (1998), Sabir (1999), and Shafique (2002) concluded that academic self-concept and academic achievement were strongly correlated.

The work 'Sex Differentiation and Schooling', done by Marland (1983) states that there exists a large body of literature that examined children's beliefs about their performance in matters of intellectual achievement. Girls, as compared to boys, were reported to have less confidence in their ability to succeed in challenging intellectual tasks. The book, 'Gender, Class and Education by Walker and Barton (1989) states that schooling has many patriarchal features. For the individual the dominant ideology worked to regulate cultural norms of appropriate gender behaviour, personal identity, social roles, and work and marriage roles. Thus, "girls and boys not only experience a process of acculturation at the individual level, which is strongly patriarchal in form, but also the social structure works to legitimize this ideology at the collective level" (Walker and Barton 1989:3).

In the book, Education, Gender and Democracy in Kenya, Otiende and Njoroge (2001) argue that teachers persuade girls on curriculum matters rather than advise them. This amounted to indoctrination of the girls. We need to be concerned about understanding relations of dominance and subordination in general and in particular terms. The article 'Affective variables and mathematics education' by Reyes (1984) published in Elementary School Journal, observes that there was a consistent positive correlation between selfconcept and academic achievement. Support had been found linking achievement to the development of self-concept. The findings by Reyes indicate that generally males tend to be more confident than females. Girls' lower confidence emerges from uncertainty of success when tasks performed are unfamiliar and when the past performance feedback is infrequent or ambiguous. 
In a study 'An input-output analysis of the achievement levels in secondary schools in Dominica' done by Polydore (2000), established that self-concept was pivotal in academic achievement because it correlated very well with cognitive and family background dimension. Polydore added that self-concept increased with attendance of study skills programs.

In the, Australian Journal of Education, an article titled 'self-concept configurations of high, medium and low achievers' by Everett (1991) investigated a sample of 259 female students in a catholic residential college. The results obtained showed that meaningful and consistent differences did exist between self-concept configurations of high, medium and low achievers. This shows that self-concept is positively related to achievement.

Constantine and Blackmon (2002) examined the relationship between Black American adolescent students' self-esteem and academic performance by denoting how students process academic experiences. Often students may place different levels of importance on academics based on perceived personal or societal limitations, thus leading to diminished academic outcomes (Constantine \& Blackmon, 2002). Understanding the connection between a student's self-esteem and level of several variables leads to what Shavelson, Hubner, and Stanton (1976) referred to as self-concept, which is derived from a person's response to a social or environmental situation. These authors identified seven characteristics of a person's self-concept based on specific situations and experiences.

Self-concept was viewed as (a) organized or structured, based upon experiences and meanings associated with those experiences (b) multifaceted or represented in different areas of an individuals' life, such as personal, familial, and societal views (c) hierarchical with levels of personal importance varying from individual experiences to general ideals (d) stable or established viewpoints (e) developmental and increasing in sophistication through the life span (f) evaluative or self-reflecting based on experiences and (g) differentiable or varied from other constructs affecting a person (Shavelson et al., 1976). Subsequent research on self-concept was associated with additional academic and non-academic constructs, such as examining one's beliefs about abilities in academic, social, emotional, and physical settings (Marsh, 1989; Marsh \& Shavelson, 1985). Researchers have acknowledged the significance of academic self-concept in the academic achievement outcomes of students and have supported the need for a more concise examination of ways to increase students' academic self-concept.

\section{AFFective Domain AND ACADEMIC ACHIEVEMENT}

The doctoral dissertation of Role (1995) quotes the work of Kirschenbaun and Sinson (1976) done on the effect of teaching of values-clarification lessons once a week for 18 weeks to one section of a biology class, while the control group did 
not receive the same treatment as the experimental group. The outcomes showed that the values-clarification group developed more significantly on cognitive achievement measured by the same final examination. There was no significant difference between the control group and the experimental group on attitudes towards biology and science.

The study titled 'A model to the independence of the cognitive and affective domain of objectives for the use in science technical training' by Ormerd (1983) published in the Research in Science and Technological Education Journal has proposed a diagrammatic model connecting the cognitive and affective domains of educational objectives. The study implies that success in the cognitive domain was related to affective outcomes of instruction. Lack of success therefore resulted from situations where the affective outcomes of instruction were negative.

The book, 'Closing the Achievement Gap: A Vision for Changing Beliefs and Practices' by William (2004) asserts that any form of learning must be connected with a learner's experience or entry behaviour. The author emphasizes the fact that a student's academic achievement depended on the content coverage, content exposure, content emphasis and quality of instructional delivery. Achievement gaps between boys and girls appeared as early as kindergarten. Does this mean that schooling cannot do much to close the gap that seems to originate from different social and racial conditions experienced? Does the appearance of the gap suggest the need for early intervention for those groups that were likely to fall behind academically?

One of the reasons for the existence of an achievement gap was the social class to which students belonged. The black middle class tended to score lower than their white counterparts. Students were often improperly labelled as 'learning disabled' when they simply had not been properly taught to read at a young age. A study by Polydore (2000) established that the students' perception of their teacher's behaviour in terms of both cognitive and affective criteria had a significant relationship with achievement.

\section{METHODOLOGY}

\section{DESIGN}

The causal-comparative design was mainly employed in this study. This type of design was chosen because it was considered appropriate in providing the researchers with detailed information from respondents.

Purposive random stratified sampling technique was used in the selection of schools. A list of all schools in Nandi North District was obtained from the District Education Office and used to draw up the sample size. Purposive sampling was used to eliminate those schools in Nandi North District that had not sat in Kenya Certificate of Secondary Education (KCSE) examination for the period spanning 2000 to 2004 . Stratified sampling was then used to ensure that 
all types of schools in the six different divisions of the district were covered in the sample. The schools were stratified into boys', girls', and mixed schools. The sample obtained was also classified into rural and urban schools. A sample that represented $30 \%$ of the different strata was then drawn up at random.

The sample had the following groups:

Type of school:

Mixed schools $\quad 13$

Girls' schools $\quad 3$

Boys' schools $\quad 4$

Location of school:

Urban schools $\quad 7$

Rural schools $\quad 13$

Form four Physics and Chemistry students were targeted in the selected schools. The sample of 300 students for this study consisted of $30 \%$ of boys' schools, $30 \%$ of girls' schools and $30 \%$ of co-educational schools. In addition, 146 form four Biology students were randomly picked from the 20 schools used in the study and asked to answer an open-ended questionnaire seeking to establish their reasons for not choosing Physics or Chemistry. Thus, a total of 446 students constituted the sample.

\section{RESEARCH INSTRUMENTS}

The researcher used one questionnaire for students who studied Physics, another for those who took Chemistry, and the third for those who studied Biology without Physics or Chemistry. The questionnaires for Physics and Chemistry consisted of close-ended questions modelled on a Likert-type of scale with the following scale: strongly agree (5), agree (4), disagree (3), strongly disagree (2), and undecided (1). The Biology questionnaire had open-ended questions that allowed the respondents to express their opinions about the barriers to academic performance in Physics and Chemistry.

The performance rating for the science teachers was based on a six-point scale ranging from 0 to 6 with 6 being 'Strongest' and 0 denoting 'No available information'.

\section{Methods Of Data Collection}

Data was obtained from three questionnaires answered by 408 respondents. The respondents were form four students who studied Physics, Chemistry and Biology in the year 2006. The questionnaires were based on the objectives of the study, which sought to establish the effects of the following variables on academic achievement: students' self-Concept, attitude and perception of usefulness of Physics and Chemistry according to type and location of schools. 
Respondents who studied Chemistry at Kenya Certificate of Secondary Education (KCSE) level answered the first questionnaire. The second questionnaire was administered to respondents who studied Physics at KCSE level. The third questionnaire was administered to 146 form four students who studied Biology and/with Physics or Chemistry. Examination of Physics and Chemistry at KCSE level entails a practical and a theory paper. The marks obtained in both papers for each subject are combined and a percentage calculated for the purpose of grading that subject. The award of grades depends on the overall performance in each subject in a given year. The grading is done on a 12-point scale. The highest mark is graded as A, while the lowest is awarded grade E.

\section{DEVELOPMENT OF RESEARCH INSTRUMENTS}

The questionnaire used was adapted with permission from Role's Ph.D. dissertation of 1995, titled 'Effects of Integration on College Students' Cognitive and Affective Learning in Mathematics'.

The t-test was used to compare differences between two groups of students. The $t$ - test was used because it is a parametric test, which is able to reject a false null hypothesis. To establish the relationship between the teacher's gender and attitude, self-concept and the perception of the usefulness, point-biserial correlation was used. This was a special case of Pearson's Product Moment Correlation, which is used when the independent variable is dichotomous and the dependent variables are scores.

To establish the relationship between the teacher's performance rating and attitude, self-concept and the perception of the use fullness, Pearson's Product Moment Correlation coefficient was used because the independent and the dependent variables were scores and the correlation was obtained between one independent and one dependent variable.

Section A of the questionnaire had questions to generate data on demographic information of the respondents. The questionnaires generated, in this section, information on respondents' sex, age, type of school, location of the school and the gender of the respondents' Physics and Chemistry teachers whereas Section B of the questionnaire consisted of statements on students' attitude, self-concept, perception of usefulness of the subjects, and teacher evaluation using the Likert-type of scale. This section sought answers on the respondents' perceptions on relationships between the variables that were being investigated. The statistical significance used in all analyses in this study was pegged at the 0.05 level of significance.

\section{RELIABILITY OF THE INSTRUMENTS}

To establish the reliability of the questionnaires used in this study, Internal Consistency Coefficient was calculated. This technique tested the reliability of 
items using the group of 170 respondents only once. The group of respondents was composed to form four students from two secondary schools, both from Nandi South District. Reliability was then established using Cronbach's Alpha Coefficient, which was computed to determine how items correlated to one another. A reliability coefficient of 0.79 was obtained for the items relating to students' self-concept, 0.70 for those relating to students' perceptions of the usefulness of Chemistry and Physics, 0.89 for items relating to students' attitude, and 0.86 for items that had to do with the teachers' instructional performance rating in Chemistry and Physics.

\section{ADMINISTRATION OF INSTRUMENTS}

After the Ministry of Education, Science and Technology granted the permit for the study, personal contact was made with the school principals, Physics and Chemistry teachers and forms four students of the selected schools in seeking their consent. The researchers collected data by personally visiting the schools to administer the questionnaires. The percentage return rate of the questionnaires was $91.5 \%$ (408 out of 446 questionnaires were returned duly filled). The researchers also obtained the KCSE examination results of the selected schools for a period of five years (2000 - 2004) from Nandi North District Education Office. These results were used to measure academic performance by students in Physics and Chemistry in Nandi North District.

\section{DATA ANAlysis Procedures}

Descriptive and inferential statistics were used to analyse the data. The t-test was used to compare differences in the mean scores obtained from the performance of students in Physics and Chemistry in terms of gender, type of school and location of school while Pearson's Product Moment Correlation coefficient tool was used to relate paired variables of attitude, self-concept, and perception of the usefulness of Physics and Chemistry. The analyses were used to establish relationships between variables. The level of significance used in this study was 0.05 , which is the level deemed acceptable for social science research (Best, 1991).

\section{RESUlTS AND DisCUSSION}

This study was an engagement to test if students differed in their self-concept, attitude and their perception of the usefulness of Physics and Chemistry in terms of their type of school. To test this hypothesis, $t$-test was used to compare differences in the mean scores in terms of type of school and location. Pearson's Product Moment Correlation coefficient was used to determine the relationships between independent and dependent variable.

Table 2 shows that there were no statistically significant differences in attitude toward, self-concept in and perception of the usefulness of Physics and 
Chemistry among students in single-sex and mixed schools. The mean scores in these affective variables are comparable. It is encouraging that both groups have positive attitude, self-concept and perception of usefulness in both Physics and Chemistry.

\section{Table 2}

A Comparison of Students' Attitude, Self-Concept, and Perception of the Usefulness of Physics and Chemistry in Terms of the Type of School.

\begin{tabular}{|c|c|c|c|c|c|c|}
\hline Variable & $\begin{array}{l}\text { Type of } \\
\text { School }\end{array}$ & $\mathbf{N}$ & Mean & $\begin{array}{l}\text { Standard } \\
\text { Deviation }\end{array}$ & $t$ & Prob. \\
\hline \multirow{3}{*}{$\begin{array}{l}\text { Attitude towards } \\
\text { Chemistry }\end{array}$} & Boys/Girls & 138 & 49.81 & 7.78 & \multirow{3}{*}{0.47} & \multirow{3}{*}{0.63} \\
\hline & only & & & & & \\
\hline & Mixed & 119 & 49.36 & 7.74 & & \\
\hline \multirow{3}{*}{$\begin{array}{l}\text { Attitude towards } \\
\text { Physics }\end{array}$} & Boys/Girls & 133 & 50.28 & 8.07 & \multirow{3}{*}{1.44} & \multirow{3}{*}{0.15} \\
\hline & only & & & & & \\
\hline & Mixed & 117 & 51.66 & 6.89 & & \\
\hline \multirow{3}{*}{$\begin{array}{l}\text { Self concept in } \\
\text { Chemistry }\end{array}$} & Boys/Girls & 137 & 39.09 & 7.19 & \multirow{3}{*}{1.30} & \multirow{3}{*}{0.19} \\
\hline & only & & & & & \\
\hline & Mixed & 118 & 37.89 & 7.38 & & \\
\hline \multirow{3}{*}{$\begin{array}{l}\text { Self concept in } \\
\text { Physics }\end{array}$} & Boys/Girls & 132 & 41.50 & 6.97 & \multirow{3}{*}{-0.33} & \multirow{3}{*}{0.74} \\
\hline & only & & & & & \\
\hline & Mixed & 117 & 41.76 & 5.74 & & \\
\hline \multirow{5}{*}{$\begin{array}{l}\text { Perception of } \\
\text { usefulness of } \\
\text { Chemistry } \\
\text { Perception of } \\
\text { usefulness of Physics }\end{array}$} & $\begin{array}{l}\text { Boys/Girls } \\
\text { only }\end{array}$ & 136 & 41.06 & 5.53 & \multirow[t]{2}{*}{0.39} & \multirow[t]{2}{*}{0.69} \\
\hline & Mixed & 118 & 40.80 & 5.06 & & \\
\hline & Boys/Girls & 132 & 41.36 & 5.71 & \multirow{3}{*}{0.66} & \multirow{3}{*}{0.50} \\
\hline & only & & & & & \\
\hline & Mixed & 117 & 40.82 & 7.04 & & \\
\hline
\end{tabular}

The attitude towards Physics and Chemistry and the perception of the type of school showed there was no significant difference between single-sex and coeducational school students (probability $>0.05$ ). There was no significant difference between single- sex and co- educational school (mixed) students in their self- concept in Physics and Chemistry (probability > 0.05). There was no significant difference between single- sex and co- educational school (mixed) students in their perception of the usefulness of Physics and Chemistry (probability $>0.05$ ).

The work of Marland (1983) raises the argument that girls have less confidence in their ability to succeed in challenging intellectual tasks than the boys and by implication girls have less self-concept than boys. The book by Otiende and Njuguna (2001) explains that the girls are socialized to be gentle, beautiful and obedient. The boys on the hand are made to be forceful, industrious and scientific. Thus the socialization process at home and school makes the girls what they eventually became in adulthood.

The second hypothesis tested if students differed in their self-concept, attitude and their perception of the usefulness of Physics and Chemistry in terms of the location of their school. 
Table 3

A Comparison of Attitude, Self-Concept, and Perception of Usefulness of Physics and Chemistry in Terms of Location of School.

\begin{tabular}{|c|c|c|c|c|c|c|}
\hline Affective variables & $\begin{array}{l}\begin{array}{l}\text { Location } \\
\text { of School }\end{array} \\
\end{array}$ & $\mathbf{N}$ & Mean & $\begin{array}{l}\text { Standard } \\
\text { Deviation } \\
\end{array}$ & $t$ & Prob. \\
\hline Attitude towards & Rural & 189 & 49.07 & 7.78 & & \\
\hline Chemistry & Urban & 65 & 51.04 & 7.64 & -1.76 & 0.07 \\
\hline Attitude towards & Rural & 185 & 50.75 & 7.74 & & \\
\hline Physics & Urban & 62 & 51.62 & 7.04 & -0.78 & 0.43 \\
\hline Self concept in & Rural & 187 & 38.20 & 7.21 & & \\
\hline Chemistry & Urban & 65 & 39.35 & 7.60 & -1.09 & 0.27 \\
\hline Self concept in & Rural & 184 & 41.32 & 6.60 & & \\
\hline Physics & Urban & 62 & 42.51 & 5.89 & -1.26 & 0.20 \\
\hline Perception of the & Rural & 187 & 40.52 & 5.74 & & \\
\hline $\begin{array}{l}\text { usefulness of } \\
\text { Chemistry }\end{array}$ & Urban & 64 & 42.10 & 3.69 & -2.53 & 0.01 \\
\hline $\begin{array}{l}\text { Perception of the } \\
\text { usefulness of Physics }\end{array}$ & $\begin{array}{l}\text { Rural } \\
\text { Urban }\end{array}$ & $\begin{array}{l}184 \\
62\end{array}$ & $\begin{array}{l}40.77 \\
41.98\end{array}$ & $\begin{array}{l}6.72 \\
5.26\end{array}$ & -1.28 & 0.19 \\
\hline
\end{tabular}

Students in rural and urban schools showed a statistically significant difference in their perception of the usefulness of Chemistry (probability of $0.012<0.05)$. There was no statistically significant difference between rural and urban school students in terms of their perception of the usefulness of Physics (probability of $0.199>0.05$ ). There was no statistically significant difference between rural and urban school students in terms of their self concept and attitude towards Physics and Chemistry (probability $>0.05$ ).

Similarly, urban students have better perception of the usefulness of Physics and Chemistry than the rural students. The difference in perception of the usefulness of Chemistry is statistically significant but the difference in perception of the usefulness of Physics is not statistically significant. Both rural and urban students have positive attitude and self-concept for Physics and Chemistry; they also had a good perception of the usefulness of Physics and Chemistry.

According to the work of Madaus et. al. (1979) the teacher and the school characteristics determine the student achievement. Similarly, the book written by Otiende and Njoroge (2001) emphasizes the fact that the degree or level of education one can attain is influenced by both social and economic factors that prevail in the society.

\section{CONCLUSIONS AND RECOMMENDATIONS}

This study tested if students differed in their self-concept, attitude and their perception of the usefulness of Physics and Chemistry in terms of their type and location of school. The study established that there were no statistically 
significant differences in attitude toward, self-concept in perception of the usefulness of Physics and Chemistry among students in single-sex and mixed schools. Both groups had positive attitude, self-concept and perception of usefulness in both Physics and Chemistry. Urban students had better perception of the usefulness of Physics and Chemistry than the rural students. The difference in perception of the usefulness of Chemistry is statistically significant but the difference in perception of the usefulness of Physics is not statistically significant. Both rural and urban students have positive attitude and self-concept for Physics and Chemistry; they also have a good perception of the usefulness of Physics and Chemistry. These findings indicate that the type and place of school is not a major indicator in determining the usefulness of Physics and Chemistry. Therefore, teachers from both urban and rural environments should put effort in ensuring they nurture students self-concept, attitude and perceptions by knowing the learner, articulating learning outcomes, establishing conducive learning environment, identifying teaching and learning strategies, and selecting relevant support technologies.

This study has some limitations that should be acknowledged. First, the present findings are based on self-reported data. Another limitation relates to the issue of causation, a limitation facing many non-experimental studies (Winship \& Sobel, 2004). There is need to examine the use and usefulness of science homework management strategies across rural and urban settings at the high school level, as the role of educational aspirations in science homework behaviour may be more pronounced at this level.

Another line of research should further explore the linkages between student academic achievement and science delivery strategies in both rural and urban environments. In addition to causal-comparative studies, it would be important to conduct longitudinal, non-experimental studies that follow cohorts of students to examine the linkages between academic achievement and science delivery strategies over time.

\section{REFERENCES}

Ahmad, I. (1986). Initial Development and Validation of Academic SelfConcept. Published Report. National Institute of Psychology, Quaide-Azam University, Islamabad, Pakistan.

Arnold, M. L., Newman, J. H., Gaddy, B. B., \& Dean, C. B. (2005, April 27). A look at the condition of rural education research: Setting a direction for future research. Journal of Research in Rural Education, 20 (6).

Best, W. J. (1991). Research in education. U.S.A.: Prentice-Hall, Inc.

Cobb, R. A., McIntire, W. G., \& Pratt, P. A. (1989). Vocational and educational aspirations of high school students: A problem for rural America. Research in Rural Education, 6(2), 11-23. 
Constantine, M. G., \& Blackmon, S. M. (2002). Black adolescents' racial socialization experiences: Their relations to home, school and peer self-esteem. Journal of Black Studies, 32(3), 322-335.

Education Alliance. (2004). Closing the achievement gap: A focus on rural schools. Charleston, WV: A uthor. Retrieved from http://www.educationalalliance.org.

Eider, G. H. (1963). Achievement orientations and career patterns of rural youth. Sociology of Education, 37(1), 30-58.

Everett, A.V. (1991). The self concept of high, medium and low achievers. The Australia Journal of Education, 15(3), 319-324.

Fan, X., \& Chen, M. J. (1999). Academic achievement of rural school students: A multi- year comparison with their peers in suburban and urban schools. Journal of Research in Rural Education, 15, 31-46.

Felder, R.M., Felder, G.N., Mauney, M., Hamrin, C.E., \& Dietz, E.J. (1995) Differences between rural and urban backgrounds. Journal of Engineering Education,84, 151-163.

Girls' Poor grades in science worry Lucy. (2004, April) Biosafety News: Africa's Monthly Science Newspaper, 51,1-2.

Greenberg, E. J., \& Teixeira, R. A. (1995). Non-metro student achievement on par with metro. Rural Development Perspectives, 10, 17-23.

Haas, T. (1992). What can I become: Educational aspirations of students in rural America (No. ED 345 931). ERIC Digest.

Haller, E. J., \& Virkler, S. J. (1993). Another look at rural-non-rural differences in students' educational aspirations. Journal of Research in Rural Education, 9(3), 170-178.

Haque, A., \& Sarwat, K. (1998). Age, gender, and achievement effects on academic self-concept of high school children. Pakistan Journal of Psychological Research, 13, 35-42.

Hektner, J. (1995). When moving up implies moving out: Rural adolescent conflict in the transition to adulthood. Journal of Research in Rural Education, 11(1), 3-14.

$\mathrm{Hu}, \mathrm{S}$. (2003). Educational aspirations and postsecondary access and choice: Students in urban, suburban, and rural schools compared. Education Policy Analysis Archives, 11(14).

Israel, G. D., Beaulieu, L. J., \& Hartless, G. (2001). The influence of family and community social capital on educational achievement. Rural Sociology, 66, 43-68.

Kampits, E. I. (1996). Rural partnerships in New England: Learning from kids. Journal of Research in Rural Education, 12(3), 171-177.

Kannapel, P. J., \& DeYoung, A. J. (1999). The rural school problem in 1999: A review and critique of the literature. Journal of Research in Rural Education, 15(2), 67-79.

Khattri, N., Riley, K. W., \& Kane, M. B. (1997). Students at risk in poor, rural areas: A review of the research. Journal of Research in Rural Education, 
13(2), 79-100.

Kelly, A. \& Smail, B.(1986). Sex stereotypes and attitudes to science among eleven-year old children. British Journal of Educational Psychology, 56 (2), 158-168.

Ley, J., Nelson, S., \& Beltyukova, S. (1996). Congruence of aspirations of rural youth with expectations held by parents and school staff. Journal of Research in Rural Education, 12(3), 133-141.

Madaus, G. F., Kellaghan, T., Rakow, E. A., \& King, D. J. (1979). The sensitivity measures of school effectiveness. Harvard Educational Review, 49(2), 207-225.

Marland, M. (Ed.) (1983). Sex differentiation and schooling.London: Heinemann.

Marsh, H. W., \& Shavelson, R. (1985). Self-concept: It's Multifaceted, Hierarchical Structure. Educational Psychologist, 20, 107-125.

Marsh, H. W. (1989). Age and sex effects in multiple dimensions of selfconcept: preadolescence to early-adulthood. Journal of Educational Psychology, 81, 417-430.

Miller, R. B., \& Brickman, S. J. (2004). A model of future-oriented motivation and self-regulation. Educational Psychology Review, 16, 9-33.

Ormerod, M. B. (1983). A model to exhibit the independence of the cognitive and affective domain of objectives for the use in science and technical teacher training. Research in Science and Technological Education. 1(1), 119-128.

Ormrod, J. E. (2000). Educational Psychology: Developing Learners. PrenticeHall, Inc, New Jersey,USA, 80-83.

Purkey, W. W. (1970). Self-concept and Academic Achievement. Englewood Cliffs, Printice-Hall. New Jersey, USA.

Otiende, J. E., \& Njoroge, G. K. (2001). Education, Gender and Democracy in Kenya. Nairobi: Quest and Insight Publishers.

Reeves, E. B., \& Bylund, R. A. (2005). Are rural schools inferior to urban schools? A multilevel analysis of school accountability trends in Kentucky. Rural Sociology, 70, 360-386.

Reyes, L. H. (1984). Affective variables and mathematics education. Elementary School Journal, 84, 558-581.

Role, E. M. (1995). Effects of values integration on college students' cognitive and affective learning's in mathematics. Unpublished Ph.D. Dissertation, University of the Philippines, Quezon City.

Roscigno, V. J., \& Crowley, M. L. (2001). Rurality, institutional disadvantage, and achievement/attainment. Rural Sociology, 66, 268-292.

Sabir, F. (1999). Academic Self-concept and Achievement among University Students as Related to their Psychological Adjustment. (Unpublished M.Phil Thesis). National Institute of Psychology, Quaid-e-Azam University, Islamabad, Pakistan.

Sanchez, F. J. P., \& Roda, M. D. S. (2007). Relationship between Self- 
concept and Academic Achievement in Primary Students. Almeria, Spain. P. 97.

Shafique, A. (2002). Relationship Between Academic Self-concept and Academic Achievement among School Children, National Institute of Psychology, Quaid-e-Azam University, Islamabad., Pakistan.

Shavelson, R. J., Hubner, J. J., \& G. C. Stanton.( 1976). Validation of Construct Interpretations. Review of Educational Research. 46, 407441.

Stern, J. D. (Ed.) (1994). The condition of education in rural schools. Washington, DC: U.S. Department of Education, Office of Educational Research and Improvement, Programs for the Improvement of Practice.

Schutz, P. A. (1997). Educational goals, strategies use, and the academic performance of high school students. High School Journal, 80, 193-201.

Walker, S., \& Barton, L. (Eds.) (1989). Gender, class and education. London: Falmer.

Webster, B. J., \& Fisher, D. L. (2000). Accounting for variation in science and mathematics achievement: A multilevel analysis of Australian data. School Effectiveness and School Improvement,11,339-360.

William, B. (Ed.) (2004). Closing the achievement GAP: A vision for changing beliefs and practices. Virginia: ASCD.

Williams, J. H. (2005). Cross-national variations in rural mathematics achievement: A descriptive overview. Journal of Research in Rural Education, 20, 1-18. Retrieved April 27, 2005 from www.umaine.edu /jrre/20-5.htm.

Winship, C., \& Sobel, M. E. (2004). Causal inferences in sociological studies. In M. Hardy \& A. Bryman (Eds.), Handbook of data analysis (481503). Thousand Oaks, CA: Sage.

Woolfolk, A. E. (1998). Educational Psychology (74-75). Allyn \& Bacon, USA.

Young, D. (1998). Rural and urban differences in student achievement in science and mathematics: A multilevel analysis. School Effectiveness and School Improvement, 9, 386-418.

Young, D. (2000). Rural differences in student achievement: The effect of student perceptions. Educational Research and Evaluation, 6, 207-228.

Zimmerman, B. J., \& Kitsantas, A. (2005). Homework practices and academic achievement: The mediating role of self-efficacy and perceived responsibility beliefs. Contemporary Educational Psychology, 30, 397417.

Zimmerman, B. J., \& Martinez-Pons, M. (1990). Student differences in selfregulated learning: Relating grade, sex, and giftedness to selfefficacy and strategy use. Journal of Educational Psychology, 82, 51-59. 